Article

\title{
Amino Acid-Derived Metabolites from the Ascidian Aplidium sp.
}

\section{Tae Hyung Won ${ }^{1}$, Chang-Kwon Kim ${ }^{1}$, So-Hyoung Lee ${ }^{2}$, Boon Jo Rho ${ }^{3}$, Sang Kook Lee ${ }^{1}$, Dong-Chan Oh ${ }^{1}$, Ki-Bong $\mathrm{Oh}^{2, *}$ and Jongheon Shin ${ }^{1, *}$}

1 Natural Products Research Institute, College of Pharmacy, Seoul National University, San 56-1, Sillim, Gwanak, Seoul 151-742, Korea; E-Mails: wth123@snu.ac.kr (T.H.W.); kck1006@snu.ac.kr (C.-K.K.); sklee61@snu.ac.kr (S.K.L.); dongchanoh@snu.ac.kr (D.-C.O.) Department of Agricultural Biotechnology, College of Agriculture and Life Science, Seoul National University, San 56-1, Sillim, Gwanak, Seoul 151-921, Korea; E-Mail: awhee84@naver.com

3 Department of Biological Science, College of Life Science, Ewha Womans University, 52, Ewhayeodae-gil, Seodaemun, Seoul 120-750, Korea; E-Mail: nhm@ewha.ac.kr

* Authors to whom correspondence should be addressed; E-Mails: ohkibong@snu.ac.kr (K.-B.O.); shinj@snu.ac.kr (J.S.); Tel.: +82-2-880-4646 (K.-B.O.); +82-2-880-2484 (J.S.); Fax: +82-2-873-3112 (K.-B.O.); +82-2-762-8322 (J.S.).

Academic Editor: Orazio Taglialatela-Scafati

Received: 21 April 2015 / Accepted: 5 June 2015 / Published: 16 June 2015

\begin{abstract}
Four new iodobenzene-containing dipeptides (1-4), a related bromotryptophancontaining dipeptide (5), and an iodophenethylamine (6) were isolated from the ascidian Aplidium sp. collected off the coast of Chuja-do, Korea. The structures of these novel compounds, designated as apliamides A-E (1-5) and apliamine A (6) were determined via combined spectroscopic analyses. The absolute configuration of the amino acid residue in $\mathbf{1}$ was determined by advanced Marfey's analysis. Several of these compounds exhibited moderate cytotoxicity and significant inhibition against $\mathrm{Na}^{+} / \mathrm{K}^{+}$-ATPase (4).
\end{abstract}

Keywords: dipeptides; apliamides; Aplidium sp.; Marfey’s analysis; bioactivities

\section{Introduction}

Ascidians (phylum Chordata, class Ascidiacea) are widely recognized as prolific sources of bioactive secondary metabolites that have attracted significant interest in the biomedical field [1-7]. The most noticeable example of an ascidian-derived drug is the recently developed anticancer agent, Yondelis 
(ecteinascidin 743), from the Caribbean ascidian Ecteinascidia turbinata [2-9]. Other notable examples under clinical trials for anticancer agents include aplidine from Aplidium albicans [10,11] and diazonamide from Diazona angulata [12].

The most distinctive feature of ascidian metabolites from other marine-derived compounds is the significant occurrence of amino-acid derived metabolites that have a great diversity of amino acid residues and functionalities [1]. Of these metabolites, those containing iodinated amino acid residues are scarce and have a limited distribution compared with other residues halogenated with chlorine or bromine [13]. Since the first isolation of two iodinated phenethylamines from Didemnum sp. [14], compounds of this structural class have been found from a few animals of the genera Aplidium [15] and Didemnum [16-18]. These metabolites have exhibited diverse bioactivities, such as cytotoxicity [14,15], antifungal activity [14] and the inhibition of glutathione reductase [15].

In our continuing search for bioactive metabolites from Korean ascidians [19-22], we recently encountered the reddish orange Aplidium sp. off the coast of Chuja-do, Korea, whose organic extract exhibited significant cytotoxicity ( $\mathrm{IC}_{50} 38.6 \mu \mathrm{g} / \mathrm{mL}$ ) for the A549 cancer cell-line. The bioassay-guided separation of the crude extract using diverse chromatographic methods yielded several peptide metabolites. In this study, we report the structural determination of six new compounds: apliamides A-D (1-4), four iodobenzene-containing dipeptides, apliamide E (5), a related bromotryptophan-containing dipeptide, and apliamine A (6), an iodinated phenethylamine (Figure 1). Several of these compounds exhibited moderate cytotoxicity for the K562 and A549 cell-lines, and apliamide D (4) significantly inhibited the action of $\mathrm{Na}^{+} / \mathrm{K}^{+}$-ATPase.

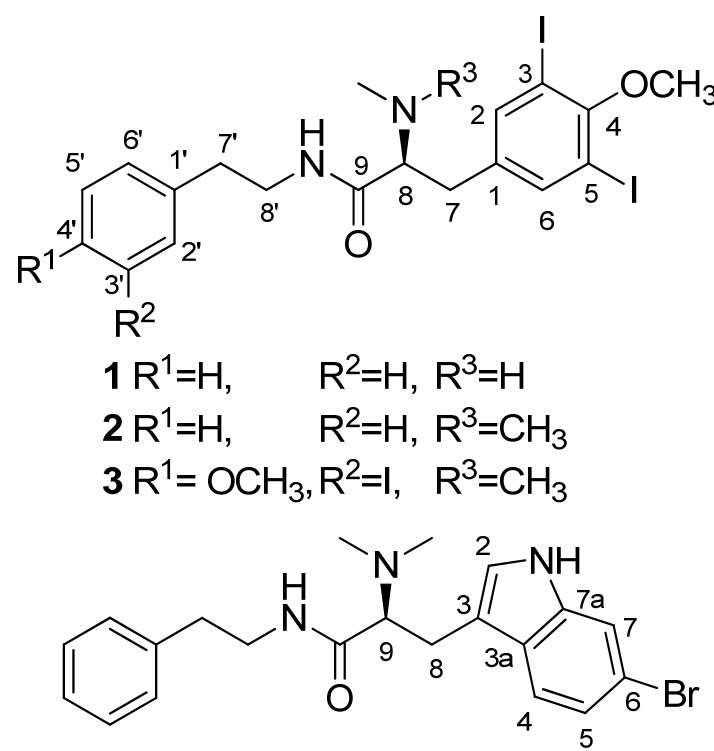

5<smiles>COc1c(I)cc(/C=C/C(=O)NCCc2ccccc2)cc1I</smiles>

4<smiles>COc1c(I)cc(CCN(C)C)cc1I</smiles>

6

Figure 1. Structures of compounds 1-6.

\section{Results and Discussion}

Compound 1 was isolated as an amorphous solid, which was analyzed by HRFABMS and determined to be $\mathrm{C}_{19} \mathrm{H}_{22} \mathrm{~N}_{2} \mathrm{O}_{2} \mathrm{I}_{2}$, containing 9 degrees of unsaturation. However, the ${ }^{13} \mathrm{C}$ NMR data showed only fifteen carbon signals. Of these signals, eight carbons in the downfield region of $\delta_{c} 142.0-91.1$ showed 
highly disproportionate intensities. This spectroscopic feature, along with the corresponding proton signals at $\delta_{\mathrm{H}} 7.66-7.11$ in the ${ }^{1} \mathrm{H}$ NMR data, strongly imply the presence of two symmetric benzene moieties (Table 1). A carbonyl carbon at $\delta \mathrm{c} 173.3$ is indicative of an amide group, which was also supported by the characteristic absorption band at $1655 \mathrm{~cm}^{-1}$ in the IR data. The remaining signals in the ${ }^{13} \mathrm{C}$ NMR data included one methine, three methylenes and two methyl carbons in the upfield region.

Table 1. NMR Data of Compounds 1 and 2 in MeOH- $d 4$.

\begin{tabular}{|c|c|c|c|c|}
\hline \multirow[b]{2}{*}{ Position } & \multicolumn{2}{|r|}{1} & \multicolumn{2}{|r|}{2} \\
\hline & $\delta_{\mathrm{C}}$, Type & $\delta_{\mathrm{H}}$, mult $(J$ in $\mathrm{Hz})$ & $\delta_{\mathrm{C}}$, Type & $\delta_{\mathrm{H}}$, mult $(J$ in $\mathrm{Hz})$ \\
\hline 1 & $138.2, \mathrm{C}$ & & $139.8, \mathrm{C}$ & \\
\hline $2 / 6$ & $142.0, \mathrm{CH}$ & $7.66, \mathrm{~s}$ & 142.0, $\mathrm{CH}$ & 7.67, s \\
\hline $3 / 5$ & $91.1, \mathrm{C}$ & & $90.9, \mathrm{C}$ & \\
\hline 4 & 159.5, C & & 159.1, C & \\
\hline \multirow[t]{2}{*}{7} & $37.9, \mathrm{CH}_{2}$ & 2.76, dd $(13.5,8.5)$ & $34.9, \mathrm{CH}_{2}$ & $2.78, \mathrm{dd}(12.0,5.0)$ \\
\hline & & $2.82, \mathrm{dd}(13.5,6.5)$ & & $2.89, \mathrm{dd}(12.0,11.0)$ \\
\hline 8 & $66.0, \mathrm{CH}$ & $3.23, \mathrm{dd}(8.5,6.5)$ & $71.8, \mathrm{CH}$ & $3.02, \mathrm{dd}(11.0,5.0)$ \\
\hline 9 & 173.3, C & & $172.2, \mathrm{C}$ & \\
\hline $1^{\prime}$ & $140.2, \mathrm{C}$ & & 140.3, C & \\
\hline $2^{\prime} / 6^{\prime}$ & $129.7, \mathrm{CH}$ & $7.11, \mathrm{~d}(8.0)$ & $129.7, \mathrm{CH}$ & $7.05, \mathrm{~d}(7.5)$ \\
\hline $3^{\prime} / 5^{\prime}$ & $129.6, \mathrm{CH}$ & $7.24, \mathrm{t}(8.0)$ & $129.5, \mathrm{CH}$ & $7.22, \mathrm{t}(7.5)$ \\
\hline $4^{\prime}$ & $127.4, \mathrm{CH}$ & $7.16, \mathrm{t}(8.0)$ & $127.3, \mathrm{CH}$ & $7.14, \mathrm{t}(7.5)$ \\
\hline \multirow[t]{2}{*}{$7^{\prime}$} & $36.7, \mathrm{CH}_{2}$ & 2.57, ddd $(14.0,7.5,6.5)$ & $36.8, \mathrm{CH}_{2}$ & 2.51, ddd $(14.0,7.5,7.0)$ \\
\hline & & 2.67, ddd $(14.0,8.0,7.5)$ & & 2.64, ddd $(14.0,7.5,7.0)$ \\
\hline \multirow[t]{2}{*}{$8^{\prime}$} & $41.7, \mathrm{CH}_{2}$ & 3.25 , ddd $(14.0,7.5,7.5)$ & 41.6, $\mathrm{CH}_{2}$ & 3.17 , ddd $(13.5,7.0,7.0)$ \\
\hline & & 3.44, ddd $(14.0,8.0,6.5)$ & & 3.43, ddd $(13.5,7.5,7.5)$ \\
\hline 4-OMe & $61.1, \mathrm{CH}_{3}$ & $3.77, \mathrm{~s}$ & $61.1, \mathrm{CH}_{3}$ & $3.76, \mathrm{~s}$ \\
\hline 8-NMe & $34.0, \mathrm{CH}_{3}$ & $2.28, \mathrm{~s}$ & $42.5, \mathrm{CH}_{3}(2 \mathrm{C})$ & $2.29, \mathrm{~s}(6 \mathrm{H})$ \\
\hline
\end{tabular}

The structure of 1 was then elucidated by a combination of ${ }^{1} \mathrm{H}-{ }^{1} \mathrm{H}$ COSY, HSQC and HMBC analyses. All of the protons and their attached carbons were precisely matched by the HSQC data. The long-range couplings of two singlet methine protons at $\delta_{\mathrm{H}} 7.66$ with the neighboring carbons in the HMBC data revealed the presence of a 1,3,4,5-tetrasubstituted benzene moiety (Figure 2). The unusually strong shielding of the $\mathrm{C}-3$ and $\mathrm{C}-5$ carbons at $\delta_{\mathrm{C}} 91.1$ indicated the placement of iodine atoms at these positions. Similarly, a methoxy group was located at C-4 according to the deshielding of this carbon at $\delta_{\mathrm{C}} 159.5$ as well as its long-range correlation with the methoxy proton at $\delta_{\mathrm{H}} 3.77$. Thus, the 3,5-diiodo-4-methoxyphenyl moiety (C-1 C-6 and 4-OMe) was adequately determined. The sequential linkage at $\mathrm{C}-1$ with a methylene $\left(\mathrm{C}-7, \delta_{\mathrm{C}} 37.9, \delta_{\mathrm{H}} 2.76\right.$ and 2.82$)$, a methine $\left(\mathrm{C}-8, \delta_{\mathrm{C}} 66.0, \delta_{\mathrm{H}} 3.23\right)$ and a carbonyl carbon $\left(\mathrm{C}-9, \delta_{\mathrm{C}} 173.3\right)$ was verified by the COSY correlations between $\mathrm{H}-7$ and $\mathrm{H}-8$, as well as several $\mathrm{HMBC}$ correlations among these protons and the neighboring carbons, as follows: $\mathrm{H}-2$, -6/C-7; H-7/C-1, C-2, C-6, C-8, and C-9; H-8/C-1, C-7, and C-9. An N-methyl group ( $\delta$ c 34.0, $\left.\delta_{\mathrm{H}} 2.28\right)$ was located at $\mathrm{C}-8$ according to the mutual $\mathrm{HMBC}$ correlations with the $\mathrm{C}-8$ methine, $\mathrm{H}-8 / \mathrm{C}-\mathrm{NMe}$; H-NMe/C-8.

The proton-proton coupling patterns among the five protons at $\delta_{\mathrm{H}} 7.24-7.11$ in the COSY data indicated the presence of a phenyl group $\left(\mathrm{C}-1^{\prime}-\mathrm{C}-6^{\prime}\right)$, which was confirmed by the HMBC correlations 
between these aromatic protons and the neighboring carbons. The sequential linkage of this phenyl group with two methylenes $\left(C-7^{\prime}, \delta_{\mathrm{C}} 36.7, \delta_{\mathrm{H}} 2.57\right.$ and 2.67 ; C-8', $\delta_{\mathrm{C}} 41.7, \delta_{\mathrm{H}} 3.25$ and 3.44) was also confirmed by the COSY correlations among the methylene protons; this confirmation was aided by the HMBC data of $\mathrm{H}-2^{\prime},-6^{\prime} / \mathrm{C}-7^{\prime} ; \mathrm{H}-7^{\prime} / \mathrm{C}-1^{\prime}, \mathrm{C}-2^{\prime}, \mathrm{C}-6^{\prime}$ and $\mathrm{C}-8^{\prime} ; \mathrm{H}-8^{\prime} / \mathrm{C}-1^{\prime}$. The carbon and proton chemical shifts of the $\mathrm{C}-8^{\prime}$ methylene group suggested the direct attachment of a nitrogen at this position. Thus, the phenethylamine moiety was determined.

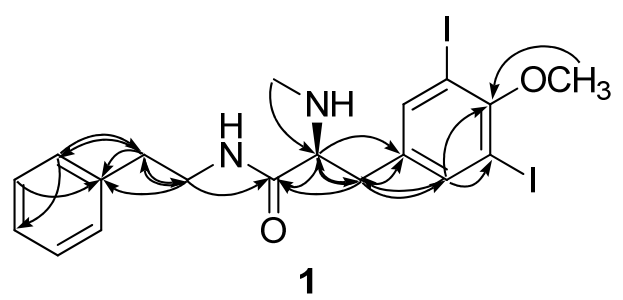

Figure 2. Selected HMBC correlations for compound 1.

The connectivity of the two phenyl-containing partial structures was also determined by the HMBC data. The long-range couplings of the $\mathrm{H}-8^{\prime}$ methylene protons at $\delta_{\mathrm{H}} 3.25$ and 3.44 with the $\mathrm{C}-9$ carbonyl carbon at $\delta_{\mathrm{C}} 173.3$ suggested the presence of an amide linkage. This interpretation was further supported by the ESI-Q-TOF-MS/MS analysis in which a noticeable fragment resulting from the $\alpha$-cleavage of an amide bond was obtained (See Supporting Information, Figure S1). Thus, the structure of 1, designated apliamide A, was determined to be a new iodobenzene-containing dipeptide.

Apliamide A (1) possessed an asymmetric carbon center at the C-8 of the iodotyrosine-derived unit. The absolute configuration of this amino acid residue was determined by advanced Marfey's analysis. [23,24] After the acidic hydrolysis of 1, the ESI-LC/MS analysis of the hydrolysate adducts with L- and D-FDAA (Marfey's reagent, 1-fluoro-2-4-dinitrophenyl-5-L(or D)-alanine amide) confirmed the NMR-based structural elucidation of the iodotyrosine-derived unit. An L configuration was also assigned at C-8 from the shorter LC retention time of the L-FDAA adduct compared with the countering D-FDAA adduct (See Experimental Section). The elution order of L- and D-FDAA adduct was dependent on the difference in hydrophobicity between the $\alpha$-carboxyl group and the iodinated phenyl group of an amino acid residue. An L-FDAA adduct with a trans-type arrangement of two more hydrophobic substituents at both $\alpha$-carbons of an amino acid and L-alanine amide moieties is eluted before D-FDAA adduct with a cis-type arrangement of those [25].

The molecular formula of apliamide $\mathrm{B}(2)$ was established as $\mathrm{C}_{20} \mathrm{H}_{25} \mathrm{~N}_{2} \mathrm{O}_{2} \mathrm{I}_{2}$ via HRFABMS analysis. The ${ }^{1} \mathrm{H}$ and ${ }^{13} \mathrm{C}$ NMR data of this compound were very similar to those of $\mathbf{1}$ with the additional presence of signals representing a methyl group $\left(\delta_{\mathrm{C}} 42.5, \delta_{\mathrm{H}} 2.29\right)$, which was the most noticeable difference (Table 1). The combined 2D NMR data were nearly identical to those of $\mathbf{1}$, implying the same aromatic dipeptide nature. The new methyl group was located at 8-NMe based on its carbon and proton chemical shifts, singlet proton multiplicity, and the crucial HMBC correlations at H-8/C-NMe and H-NMe/C-8. This interpretation was confirmed by ESI-MS/MS analysis in which a fragment containing the 8 - $N, N$-dimethyl group was obtained (See Supporting Information, Figure S1). The similar specific rotation of +11.2 and +12.2 for $\mathbf{1}$ and $\mathbf{2}$, respectively, suggested the same L configuration at C-8 for 2 . Thus, the structure of apliamide B (2) was determined as the 8-NMe derivative of $\mathbf{1}$. 
Apliamide C (3) was isolated as an amorphous solid with a molecular formula of $\mathrm{C}_{21} \mathrm{H}_{2} \mathrm{~N}_{2} \mathrm{O}_{3} \mathrm{I}_{3}$ via HRFABMS analysis. The ${ }^{13} \mathrm{C}$ and ${ }^{1} \mathrm{H}$ NMR data of this compound were reminiscent of 2 , revealing the same dipeptide features. However, the detailed examination of the NMR data revealed that the phenyl moiety (C-1'-C-6') was substituted by the following two substituents: an iodine and a methoxy group $\left(\delta_{\mathrm{C}} 56.9, \delta_{\mathrm{H}} 3.82\right)$ (Table 2). The chemical shifts and coupling patterns of the three aromatic protons at $\delta_{\mathrm{H}} 6.82(1 \mathrm{H}, \mathrm{d}, J=8.0 \mathrm{~Hz}), 6.97(1 \mathrm{H}, \mathrm{dd}, J=8.0,2.0 \mathrm{~Hz})$, and $7.51(1 \mathrm{H}, \mathrm{d}, J=2.0 \mathrm{~Hz})$ in the ${ }^{1} \mathrm{H} \mathrm{NMR}$ data were characteristic of an ABX spin system. Based on the results of the combined 2D NMR data, including the key HMBC correlations of these protons with neighboring carbons, the iodine and methoxy groups were located at C-3' and C-4', respectively. The ESI-MS/MS data provided a fragment derived by the $\alpha$-cleavage of the amide bond, supporting the NMR-determined structure (See Supporting Information, Figure S1). Thus, the structure of apliamide C (3) was determined as a dipeptide containing two iodinated phenyl moieties.

Table 2. NMR Data of Compounds 3 in $\mathrm{MeOH}-d_{4}$ and 4 in $\mathrm{CDCl}_{3}$.

\begin{tabular}{|c|c|c|c|c|}
\hline \multirow[b]{2}{*}{ Position } & \multicolumn{2}{|r|}{3} & \multicolumn{2}{|r|}{4} \\
\hline & $\delta_{\mathrm{C}}$, Type & $\delta_{\mathrm{H}}$, mult $(J$ in Hz$)$ & $\delta_{\mathrm{C}}$, Type & $\delta_{H}$, mult $(J$ in $\mathrm{Hz})$ \\
\hline 1 & $135.4, \mathrm{C}$ & & $134.8, \mathrm{C}$ & \\
\hline $2 / 6$ & $142.3, \mathrm{CH}$ & $7.72, \mathrm{~s}$ & $138.9, \mathrm{CH}$ & $7.86, \mathrm{~s}$ \\
\hline $3 / 5$ & $91.5, \mathrm{C}$ & & $90.8, \mathrm{C}$ & \\
\hline 4 & $160.2, \mathrm{C}$ & & $159.8, \mathrm{C}$ & \\
\hline \multirow[t]{2}{*}{7} & $33.9, \mathrm{CH}_{2}$ & $2.94, \mathrm{dd}(11.5,11.5)$ & $138.7, \mathrm{CH}$ & $7.41, \mathrm{~d}(15.0)$ \\
\hline & & $3.27, \mathrm{dd}(11.5,5.0)$ & & \\
\hline 8 & $70.8, \mathrm{CH}$ & $3.73, \mathrm{dd}(11.5,5.0)$ & $122.1, \mathrm{CH}$ & $6.21, \mathrm{~d}(15.0)$ \\
\hline 9 & 167.1, C & & 165.0, C & \\
\hline $1^{\prime}$ & $133.9, \mathrm{C}$ & & 137.3, C & \\
\hline $2^{\prime}$ & $131.0, \mathrm{CH}$ & $7.51, \mathrm{~d}(2.0)$ & $128.8, \mathrm{CH}$ & 7.22, d (7.5) \\
\hline $3^{\prime}$ & $86.5, \mathrm{C}$ & & $128.7, \mathrm{CH}$ & $7.33, \mathrm{t}(7.5)$ \\
\hline $4^{\prime}$ & $158.5, \mathrm{C}$ & & 126.7, CH & $7.25, \mathrm{~d}(7.5)$ \\
\hline $5^{\prime}$ & $112.2, \mathrm{CH}$ & $6.82, \mathrm{~d}(8.0)$ & $128.7, \mathrm{CH}$ & 7.33, d (7.5) \\
\hline $6^{\prime}$ & $140.6, \mathrm{CH}$ & $6.97, \mathrm{dd}(8.0,2.0)$ & $128.8, \mathrm{CH}$ & $7.22, \mathrm{~d}(7.5)$ \\
\hline \multirow[t]{2}{*}{$7^{\prime}$} & $34.9, \mathrm{CH}_{2}$ & 2.36 , ddd $(14.0,7.5,7.5)$ & $35.6, \mathrm{CH}_{2}$ & $2.89, \mathrm{t}(7.0)$ \\
\hline & & 2.53, ddd $(14.0,7.5,5.5)$ & & \\
\hline \multirow[t]{2}{*}{$8^{\prime}$} & $41.7, \mathrm{CH}_{2}$ & 3.22 , ddd $(13.5,7.5,5.5)$ & $40.8, \mathrm{CH}_{2}$ & $3.67, \mathrm{dt}(7.0,6.5)$ \\
\hline & & 3.34, ddd $(13.5,7.5,7.5)$ & & \\
\hline 4-OMe & $61.2, \mathrm{CH}_{3}$ & $3.79, \mathrm{~s}$ & $60.8, \mathrm{CH}_{3}$ & $3.86, \mathrm{~s}$ \\
\hline $4^{\prime}-\mathrm{OMe}$ & $56.9, \mathrm{CH}_{3}$ & $3.82, \mathrm{~s}$ & & \\
\hline 8-NMe & $42.5, \mathrm{CH}_{3}(2 \mathrm{C})$ & $3.87, \mathrm{~s}(6 \mathrm{H})$ & & \\
\hline $8^{\prime}-\mathrm{NH}$ & & ND & & $5.57, \mathrm{t}(6.5)$ \\
\hline
\end{tabular}

The molecular formula of apliamide D (4) was deduced as $\mathrm{C}_{18} \mathrm{H}_{17} \mathrm{NO}_{2} \mathrm{I}_{2}$ via HRFABMS analysis. The ${ }^{13} \mathrm{C}$ and ${ }^{1} \mathrm{H}$ NMR data of this compound were similar to those of $\mathbf{1}$, revealing the same dipeptide nature for 4. The most noticeable differences in the NMR data were the lack of signals for the 8-NMe group, consistent with the mass spectral data. In addition, the C-7 and C-8 aliphatic carbons were replaced with olefinic methines $\left(\delta_{\mathrm{C}} 138.7\right.$ and $122.1, \delta_{\mathrm{H}} 7.41$ and 6.21) in 4 (Table 2). These interpretations were 
confirmed by the combined 2D NMR data. Crucial evidence was provided by the HMBC data in which several correlations were obtained between the olefinic protons and the neighboring carbons, as follows: H-7 ( $\left.\delta_{\mathrm{H}} 7.41\right) / \mathrm{C}-1, \mathrm{C}-2, \mathrm{C}-6, \mathrm{C}-8$, and C-9; H-8 ( $\left.\delta_{\mathrm{H}} 6.21\right) / \mathrm{C}-1, \mathrm{C}-7$, and C-9 (Figure 3). The $E$ configuration was assigned to the $\mathrm{C}-7$ double bond based on the large vicinal coupling constant between the olefinic protons $\left(J_{7,8}=15.0 \mathrm{~Hz}\right)$. The NMR interpretation was also confirmed by ESI-MS/MS analysis in which a fragment derived from the cleavage of the C-9 amide bond was observed (See Supporting Information, Figure S1). Thus, the structure of the apliamide D (4) was determined as a linear peptide possessing a degraded amino acid.

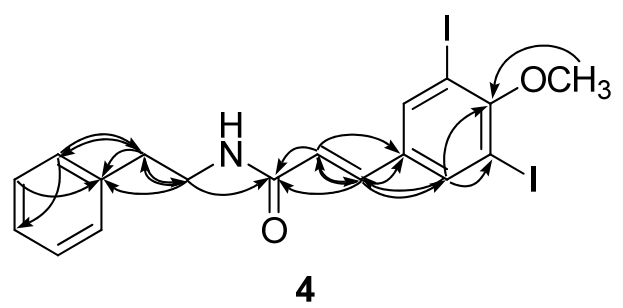

Figure 3. Selected HMBC correlations for compound 4.

In addition to the iodinated benzene-containing dipeptides, a dipeptide possessing a different building block was isolated and structurally elucidated. The molecular formula of compound $\mathbf{5}$ was established as $\mathrm{C}_{21} \mathrm{H}_{24} \mathrm{~N}_{3} \mathrm{OBr}$ via HRFABMS analysis. A detailed examination of the NMR data revealed that this compound possessed several partial structures that are identical to the other apliamides, as follows: propionamide (C-7-C-9), the phenethylamine moiety $\left(\mathrm{C}-1^{\prime}-\mathrm{C}-8^{\prime}\right)$ and the $N, N$-dimethyl group (8-NMe $)$ (Table 3). Therefore, the structural difference must occur at the diiodomethoxybenzene moiety, which was replaced with an aromatic moiety having $\mathrm{C}_{8} \mathrm{H}_{5} \mathrm{NBr}$ as part of its formula.

The new moiety was thought to be a bromoindole because of the characteristic quaternary carbon at $\delta_{\mathrm{C}} 138.9(\mathrm{C}-7 \mathrm{a})$ and a singlet proton at $\delta_{\mathrm{H}} 7.16(\mathrm{H}-2)$ in the NMR data [26]. This interpretation was fully confirmed by the combined 2D NMR data, including the long-range correlations between the aromatic protons and the neighboring carbons in the HMBC data. The placement of bromine at C- 6 of the indole was accomplished using the $\mathrm{ABX}$-type proton coupling pattern of $\mathrm{H}-4, \mathrm{H}-5$ and $\mathrm{H}-7$, in addition to the HMBC correlations at H-4 and H-7 with C-6. Similarly the direct linkage between the C-8 ethyl group and the $\mathrm{C}-3$ of the indole was confirmed by the HMBC correlations, as follows: H-2/C-8; H-8/C-2, C-3, $\mathrm{C}-3 \mathrm{a} ; \mathrm{H}-9 / \mathrm{C}-3$. Further confirmation was provided by the ESI-MS/MS data in which a fragment containing a bromoindole moiety was obtained (See Supporting Information, Figure S1). Thus, the structure of apliamide E (5) was determined as a dipeptide possessing a tryptophan-derived unit corresponding to the tyrosine-derived units of other apliamides.

Apliamide E (5) contained an asymmetric carbon center at the C-9 of the tryptophan-derived unit. Due to the highly unstable nature of the hydrolysates, however, further chemical analyses were unsuccessful under the diverse reaction conditions [27]. The absolute configuration was finally assigned as $L$ by the comparison of the specific rotation $\left([\alpha]_{\mathrm{D}}^{25}+5.0\right)$ sign with a related tryptophan compound (L-N,N-dimethyltryptophan methyl ester, $\left.[\alpha]_{\mathrm{D}}^{25}+65.0\right)[28]$. 
Table 3. NMR Data of Compound 5 in $\mathrm{MeOH}-d_{4}$.

\begin{tabular}{|c|c|c|}
\hline \multirow[b]{2}{*}{ Position } & \multicolumn{2}{|r|}{5} \\
\hline & $\delta_{\mathrm{C}}$, Type & $\delta_{\mathrm{H}}$, mult $(J$ in $\mathrm{Hz})$ \\
\hline 2 & $126.5, \mathrm{CH}$ & $7.16, \mathrm{~s}$ \\
\hline 3 & $108.1, \mathrm{C}$ & \\
\hline $3 a$ & 127.3, C & \\
\hline 4 & $120.8, \mathrm{CH}$ & $7.47, \mathrm{~d}(8.5)$ \\
\hline 5 & $123.4, \mathrm{CH}$ & $7.18, \mathrm{~d}(8.5,1.5)$ \\
\hline 6 & $116.3, \mathrm{C}$ & \\
\hline 7 & $115.5, \mathrm{CH}$ & $7.55, \mathrm{~d}(1.5)$ \\
\hline $7 \mathrm{a}$ & $138.9, \mathrm{C}$ & \\
\hline \multirow[t]{2}{*}{8} & 25.7, $\mathrm{CH}_{2}$ & 3.29, dd $(13.5,5.0)$ \\
\hline & & $3.43, \mathrm{dd}(13.5,10.0)$ \\
\hline 9 & $70.5, \mathrm{CH}$ & 3.83 , dd $(10.0,5.0)$ \\
\hline 10 & $167.9, \mathrm{C}$ & \\
\hline $1^{\prime}$ & $139.8, \mathrm{C}$ & \\
\hline $2^{\prime} / 6^{\prime}$ & 129.7, CH & $6.90, \mathrm{~d}(7.5)$ \\
\hline $3^{\prime} / 5^{\prime}$ & $129.5, \mathrm{CH}$ & $7.15, \mathrm{t}(7.5)$ \\
\hline $4^{\prime}$ & $127.4, \mathrm{CH}$ & $7.12, \mathrm{t}(7.5)$ \\
\hline \multirow[t]{2}{*}{$7^{\prime}$} & $35.7, \mathrm{CH}_{2}$ & 2.25, ddd $(14.0,7.0,7.0)$ \\
\hline & & 2.34, ddd $(14.0,7.0,7.0)$ \\
\hline \multirow[t]{2}{*}{$8^{\prime}$} & $41.8, \mathrm{CH}_{2}$ & 3.19, ddd $(13.5,7.5,7.0)$ \\
\hline & & $3.22, \operatorname{ddd}(13.5,7.5,7.0)$ \\
\hline 9-NMe & $42.4, \mathrm{CH}_{3}(2 \mathrm{C})$ & $2.87, \mathrm{~s}(6 \mathrm{H})$ \\
\hline
\end{tabular}

In addition to the apliamide dipeptides, a biogenetically related compound was also isolated. The molecular formula of apliamine $\mathrm{A}(6)$ was deduced as $\mathrm{C}_{11} \mathrm{H}_{16} \mathrm{NOI}_{2}$ via $\mathrm{HRFABMS}$ analysis. The ${ }^{1} \mathrm{H}$ and ${ }^{13} \mathrm{C}$ NMR data of this compound were very similar to the diiodomethoxybenzene-containing unit of 2 (Table 4), which was confirmed by the combined 2D NMR analyses. Thus, the structure of apliamine A (6) was determined as a new amino acid-derived diiodomethoxyphenethylamine.

Table 4. NMR Data of Compound 6 in $\mathrm{MeOH}-d_{4}$.

\begin{tabular}{ccc}
\hline & \multicolumn{2}{c}{$\mathbf{6}$} \\
\cline { 2 - 3 } Position & $\boldsymbol{\delta}_{\mathbf{C}}$, Type & $\boldsymbol{\delta}_{\mathbf{H}}$, mult $(\boldsymbol{J}$ in Hz) \\
\hline 1 & $137.4, \mathrm{C}$ & \\
$2 / 6$ & $141.6, \mathrm{CH}$ & $7.79, \mathrm{~s}$ \\
$3 / 5$ & $91.4, \mathrm{C}$ & \\
4 & $159.8, \mathrm{C}$ & \\
7 & $29.8, \mathrm{CH}_{2}$ & $2.95, \mathrm{t}(7.5)$ \\
8 & $59.3, \mathrm{CH}_{2}$ & $3.31, \mathrm{t}(7.5)$ \\
$4-\mathrm{OMe}$ & $61.2, \mathrm{CH}_{3}$ & $3.78, \mathrm{~s}$ \\
$8-\mathrm{NMe}$ & $44.0, \mathrm{CH}_{3}(2 \mathrm{C})$ & $2.91, \mathrm{~s}(6 \mathrm{H})$ \\
\hline
\end{tabular}

The ascidian-derived iodinated amino acid metabolites exhibited cytotoxic, antimicrobial and glutathione reductase inhibitory activities [14,15]. In our bioactivity tests (Table 5), compounds 1-6 
exhibited moderate cytotoxicity ( $\mathrm{IC}_{50} 7.8-21.1 \mu \mathrm{M}$ ) for the $\mathrm{K} 562$ leukemia cell-line. Although similar trends were found for the A549 lung cancer cell-line (IC50 8.3-22.8 $\mu \mathrm{M}$ ), 1 and 4 were inactive $\left(\mathrm{IC}_{50}>100 \mu \mathrm{M}\right)$. All compounds exhibited weak cytotoxicity for MRC5 human lung fibroblast cell-line $\left(\mathrm{IC}_{50}>37.0 \mu \mathrm{M}\right)$. Compounds 3 and $\mathbf{6}$ showed no activity for a normal cell-line (MRC5, $\left.\mathrm{IC}_{50}>100 \mu \mathrm{M}\right)$ but showed moderate cytotoxicity for cancer cell-lines (K562 and A549, IC50 7.8-22.8 $\mu \mathrm{M}$ ). In addition, apliamide D (4) displayed significant inhibition for the enzyme $\mathrm{Na}^{+} / \mathrm{K}^{+}$-ATPase, (IC50 $3.2 \mu \mathrm{M}$ ), which was comparable to ouabain ( $\mathrm{IC}_{50} 6.5 \mu \mathrm{M}$ ). Interestingly, 4 was a strong inhibitor against $\mathrm{Na}^{+} / \mathrm{K}^{+}$-ATPase even it showed poor cytotoxic effect on the normal (MRC5, IC50 $>100 \mu \mathrm{M}$ ) and cancer cell lines (K562 and A549, IC 5018.2 and $>100 \mu \mathrm{M}$, respectively). None of these compounds exhibited significant antibacterial activities against the diverse Gram-positive and Gram-negative strains (MIC $>100 \mu \mathrm{g} / \mathrm{mL}$ ) or inhibition against the enzymes sortase A and isocitrate lyase, which are key enzymes in bacterial metabolism (See Supporting Information, Table S1).

Table 5. The results of bioactivity tests.

\begin{tabular}{ccccc}
\hline & K562 & A549 & MRC5 & $\mathbf{N a}^{+} / \mathbf{K}^{+}$-ATPase \\
\cline { 2 - 5 } Compound & \multicolumn{3}{c}{$\mathbf{I C}_{\mathbf{5 0}}(\boldsymbol{\mu M})$} \\
$\mathbf{1}$ & 14.3 & $>100$ & 59.2 & 163.0 \\
$\mathbf{2}$ & 21.1 & 10.8 & 73.7 & $>200$ \\
$\mathbf{3}$ & 10.4 & 13.4 & $>100$ & $>200$ \\
$\mathbf{4}$ & 18.2 & $>100$ & $>100$ & 3.2 \\
$\mathbf{5}$ & 7.8 & 22.8 & 37.0 & $>200$ \\
$\mathbf{6}$ & 19.7 & 8.3 & $>100$ & 189.2 \\
Doxorubicin & 1.2 & 1.4 & 9.8 & \\
Ouabain & & & & 6.5 \\
\hline
\end{tabular}

\section{Experimental Section}

\subsection{General Experimental Procedures}

Optical rotations were measured on a JASCO P-1020 polarimeter using a $1 \mathrm{~cm}$ cell. UV spectra were acquired with a Hitachi U-3010 spectrophotometer. IR spectra were recorded on a JASCO 4200 FT-IR spectrometer using a ZnSe cell. NMR spectra were recorded in $\mathrm{MeOH}-d_{4}$ and $\mathrm{CDCl}_{3}$ solutions containing $\mathrm{Me}_{4} \mathrm{Si}$ as an internal standard on Bruker Avance 600, 500 and 400 spectrometers. Proton and carbon NMR spectra were measured at 600 and $150 \mathrm{MHz}(\mathbf{1}, \mathbf{3}, \mathbf{4}$, and 6), 500 and $125 \mathrm{MHz}(\mathbf{5})$ or 400 and $100 \mathrm{MHz}$ (2), respectively (See Supporting Information, Figures S2-S31). The high resolution FAB mass spectrometric data were obtained at the Korea Basic Science Institute (Daegu, Korea) and acquired using a JEOL JMS 700 mass spectrometer with meta-nitrobenzyl alcohol (NBA) as a matrix for the FABMS. The low-resolution ESIMS data were recorded on an Agilent Technologies 6130 Quadrupole mass spectrometer with an Agilent Technologies 1200 series HPLC. The ESI-QTOF-MS/MS was performed on an Agilent Technologies 6530 Accurate-Mass Q-TOF LC/MS spectrometer with an Agilent Technologies 1260 series HPLC. The semi-preparative HPLC was performed on a Spectrasystem p2000 equipped with a refractive index detector (Spectrasystem RI-150) and a YMC ODS-A column $(10 \times 250 \mathrm{~mm})$. All of the solvents used were spectroscopic grade or were glass-distilled prior to use. 


\subsection{Animal Materials}

Specimens of Aplidium sp. (sample number 12CH-18) were manually collected with scuba equipment at a depth of $20 \mathrm{~m}$ off the coast of Chuja-do, Korea, on 10 October 2012. The colony was gelatinous and spherical in shape, $35 \mathrm{~mm}$ thick, $102 \mathrm{~mm}$ in maximum dimension, and attached via a large portion of the basal surface. The colony was reddish-orange live and yellowish-beige in ethanol. The zooids were beige in color and were situated perpendicularly during the test. The zooids were $1.25-9.97 \mathrm{~mm}$ in length, of which the thorax, abdomen and posterior abdomen were 0.24-0.58, 0.23-1.39 and 0.78-8.00 mm, respectively. The thorax was short with 13-14 stigma rows and an atrial tongue cleft. The gut loop was vertical and U-formed. The stomach was barrel-shaped, orange in color, and had 18-20 longitudinal folds. The posterior abdomen was very long and thread-like and occupied more than half of the body length. However, the lack of gonads and larvae prevented adequate species-level identification. The voucher specimens were deposited at the Natural History Museum, Ewha Womans University, under the curatorship of B.J.R.

\subsection{Extraction and Isolation}

Freshly collected specimens were immediately frozen and stored at $-25{ }^{\circ} \mathrm{C}$ until use. The lyophilized specimens were macerated and repeatedly extracted with $\mathrm{MeOH}(3 \mathrm{~L} \times 3)$ and $\mathrm{CH}_{2} \mathrm{Cl}_{2}(3 \mathrm{~L} \times 2)$. The combined extracts $(38.70 \mathrm{~g})$ were successively partitioned between $\mathrm{H}_{2} \mathrm{O}(25.62 \mathrm{~g})$ and $n-\mathrm{BuOH}$ $(11.50 \mathrm{~g})$; the latter fraction was repartitioned between $\mathrm{H}_{2} \mathrm{O}$ and $\mathrm{MeOH}(15: 85)(7.09 \mathrm{~g})$ and $n$-hexane $(3.99 \mathrm{~g})$. The former layer was separated by $\mathrm{C}_{18}$ reversed-phase flash chromatography using sequential mixtures of $\mathrm{MeOH}$ and $\mathrm{H}_{2} \mathrm{O}$ (six fractions in gradient, from 50:50 to 0:100), acetone, and, finally, EtOAc as the eluents.

Based on the ${ }^{1} \mathrm{H}$ NMR results and the cytotoxicity analyses, the fractions eluted with $\mathrm{H}_{2} \mathrm{O}-\mathrm{MeOH}$ (50:50; $1.12 \mathrm{~g}$ ) and $\mathrm{H}_{2} \mathrm{O}-\mathrm{MeOH}(20: 80 ; 1.00 \mathrm{~g})$ were selected for separation. The former fraction was separated by reversed-phase semi-preparative HPLC $\left(\mathrm{H}_{2} \mathrm{O}-\mathrm{MeOH}, 55: 45\right.$ with $0.01 \%$ TFA) to yield 6. The latter $\mathrm{H}_{2} \mathrm{O}-\mathrm{MeOH}(20: 80)$ fraction was separated by reversed-phase HPLC $\left(\mathrm{H}_{2} \mathrm{O}-\mathrm{MeOH}, 30: 70\right)$ to produce, in order of elution, compounds $5, \mathbf{1}, \mathbf{2}, \mathbf{4}$, and 3 as the amorphous solids. All of the isolated compounds showed high purities in the NMR data and were not further purified. The isolated amounts were $32.2,98.6,6.3,3.2,12.8$, and $5.5 \mathrm{mg}$ for $\mathbf{1}-\mathbf{6}$, respectively.

Apliamide A (1): Yellow amorphous solid; $[\alpha]_{\mathrm{D}}^{25}+12.3(c 0.50, \mathrm{MeOH}) ; \mathrm{UV}(\mathrm{MeOH}) \lambda_{\max }(\log \varepsilon) 205$ (2.75), 210 (2.74), 226 (2.71), 244 (2.41), 277 (1.85) nm; IR (ZnSe) vmax 3297, 2932, 1655, 1529, $1460 \mathrm{~cm}^{-1}$; ${ }^{1} \mathrm{H}$ and ${ }^{13} \mathrm{C}$ NMR data, see Table 1; HRFABMS $\mathrm{m} / z$ 564.9851 $[\mathrm{M}+\mathrm{H}]^{+}$(calcd for $\left.\mathrm{C}_{19} \mathrm{H}_{23} \mathrm{~N}_{2} \mathrm{O}_{2} \mathrm{I}_{2}, 564.9849\right)$.

Apliamide B (2): Yellow amorphous solid; $[\alpha]_{\mathrm{D}}^{25}+11.2\left(c\right.$ 0.50, MeOH); UV (MeOH) $\lambda_{\max }(\log \varepsilon) 205$ (2.77), 226 (2.72), 244 (2.51), 276 (2.01) nm; IR (ZnSe) v $v_{\max } 3308,2934,1658,1531,1460 \mathrm{~cm}^{-1} ;{ }^{1} \mathrm{H}$ and ${ }^{13} \mathrm{C}$ NMR data, see Table 1; HRFABMS $m / z 579.0003[\mathrm{M}+\mathrm{H}]^{+}$(calcd for $\mathrm{C}_{20} \mathrm{H}_{25} \mathrm{~N}_{2} \mathrm{O}_{2} \mathrm{I}_{2}, 579.0006$ ).

Apliamide C (3): Yellow amorphous solid; $[\alpha]_{\mathrm{D}}^{25}+10.3(c$ 0.50, $\mathrm{MeOH}) ; \mathrm{UV}(\mathrm{MeOH}) \lambda_{\max }(\log \varepsilon) 205$ (2.79), 227 (2.69), 245 (2.49), 282 (2.03) nm; IR (ZnSe) vmax 3297, 2928, 1657, 1530, $1459 \mathrm{~cm}^{-1}$; ${ }^{1} \mathrm{H}$ and ${ }^{13} \mathrm{C}$ NMR data, see Table 2; HRFABMS $m / z 734.9078[\mathrm{M}+\mathrm{H}]^{+}$(calcd for $\left.\mathrm{C}_{21} \mathrm{H}_{26} \mathrm{~N}_{2} \mathrm{O}_{3} \mathrm{I}_{3}, 734.9084\right)$. 
Apliamide D (4): Yellow amorphous solid; UV (MeOH) $\lambda_{\max }(\log \varepsilon) 205$ (2.72), 245 (2.74), 287 (2.49) nm; IR (ZnSe) $v_{\max } 3285,2932,1747,1658,1565,1461 \mathrm{~cm}^{-1} ;{ }^{1} \mathrm{H}$ and ${ }^{13} \mathrm{C}$ NMR data, see Table 2; HRFABMS $m / z 533.9424[\mathrm{M}+\mathrm{H}]^{+}$(calcd for $\mathrm{C}_{18} \mathrm{H}_{18} \mathrm{NO}_{2} \mathrm{I}_{2}, 533.9427$ ).

Apliamide E (5): Yellow amorphous solid; $[\alpha]_{\mathrm{D}}^{25}+5.0\left(c\right.$ 0.50, MeOH); UV (MeOH) $\lambda_{\max }(\log \varepsilon) 205$ (2.62), 228 (1.63), $280(2.23) \mathrm{nm}$; IR (ZnSe) $v_{\max } 3284,2929,1655,1524,1454 \mathrm{~cm}^{-1} ;{ }^{1} \mathrm{H}$ and ${ }^{13} \mathrm{C} \mathrm{NMR}$ data, see Table 3; HRFABMS $m / z$ 414.1190 [M + H] $]^{+}$(calcd for $\mathrm{C}_{21} \mathrm{H}_{25} \mathrm{~N}_{3} \mathrm{O}^{79} \mathrm{Br}, 414.1181$ ).

Apliamine A (6): White amorphous solid; UV (MeOH) $\lambda_{\max }(\log \varepsilon) 205$ (2.82), 227 (2.87), 243 (2.67), 282 (2.30) nm; IR (ZnSe) $v_{\max } 3262,2933,1622,1460 \mathrm{~cm}^{-1} ;{ }^{1} \mathrm{H}$ and ${ }^{13} \mathrm{C}$ NMR data, see Table 4; HRFABMS $m / z$ 431.9327 [M + H] $]^{+}$(calcd for $\mathrm{C}_{11} \mathrm{H}_{16} \mathrm{NOI}_{2}, 431.9321$ ).

\subsection{Advanced Marfey's Analysis of Compound 1}

Apliamide A (1, $1.2 \mathrm{mg})$ was dissolved in $12 \mathrm{~N} \mathrm{HCl}(0.5 \mathrm{~mL})$ and heated at $110{ }^{\circ} \mathrm{C}$ for $16 \mathrm{~h}$. The solution and traces of $\mathrm{HCl}$ were removed by repeated drying under vacuum with distilled water. To the divided hydrolysate $(0.6 \mathrm{mg}$ each $), 1 \mathrm{~N} \mathrm{NaHCO}_{3}(100 \mu \mathrm{L})$ and $1 \% \mathrm{~L}-$ or D-FDAA $(50 \mu \mathrm{L})$ in acetone were added. The mixture was stirred at $80{ }^{\circ} \mathrm{C}$ for $12 \mathrm{~min}$. After quenching the reaction by the addition of $2 \mathrm{~N} \mathrm{HCl}(50 \mu \mathrm{L})$, the residue was analyzed using ESI-LC/MS with a Phenomenex Luna C18 (5 $\mu \mathrm{m}$, $4.6 \mathrm{~mm} \times 150 \mathrm{~mm}$ ) analytical column. The mobile phase flow rate was $0.7 \mathrm{~mL} / \mathrm{min}$ and a gradient elution of $\mathrm{A}$ (water with $0.1 \%$ formic acid) and $\mathrm{B}(\mathrm{MeCN}$ with $0.1 \%$ formic acid) was used ( $0 \mathrm{~min}, 10 \% \mathrm{~B}$; $40 \mathrm{~min}, 70 \% \mathrm{~B}$ in A $v / v$ ). The retention times of the L- and D-FDAA-derivatized hydrolysates were 30.03 and $31.04 \mathrm{~min}$, respectively, leading to assignment of the L configuration.

\subsection{Biological Assays}

The cytotoxicity assays were performed in accordance with the literature protocols [29]. The $\mathrm{Na}^{+} / \mathrm{K}^{+}$-ATPase, isocitrate lyase, and sortase A inhibition assays were performed according to previously described methods [30-32]. The antimicrobial assays were performed according to the method described previously [33].

\section{Conclusions}

Six new metabolites, four iodobenzene containing dipeptides (1-4), a related bromotryptophan containing dipeptide (5), and an iodobenzene amine (6), were isolated from the ascidian Aplidium sp. collected from Korean waters. These compounds possessed structural novelty at their iodinated and brominated amino acid units. Several of these compounds exhibited moderate cytotoxicity for the K562 and A549 cell-lines. Additionally, apliamide D (4) exhibited significant inhibition for the enzyme $\mathrm{Na}^{+} / \mathrm{K}^{+}$-ATPase.

\section{Acknowledgments}

We thank the Basic Science Research Institute in Daegu, Korea for providing the mass spectrometric data. This study was partially supported by the BK21 Plus Program in 2015, the Medical Research Center (No. 2009-0083533) and the Basic Core Technology Development Program for the Oceans and the Polar 
Regions (No. 2010-0020429) of the National Research Foundation (NRF) funded by the Ministry of Science, ICT \& Future Planning.

\section{Author Contributions}

J.S. and K.-B.O. designed and supervised the experimental procedures and prepared the manuscript. T.H.W. and C.-K.K. isolated the compounds and obtained the spectroscopic data. S.-H.L. contributed to the cytotoxicity tests against cancer cell-lines and the enzyme inhibition tests. S.K.L. performed the cytotoxicity test for a normal cell line. D.-C.O. examined the processes of the structural determination including the advanced Marfey's reaction. B.J.R. taxonomically identified the ascidian specimen.

\section{Conflicts of Interest}

The authors declare no conflict of interest.

\section{References}

1. Blunt, J.W.; Copp, B.R.; Keyzers, R.A.; Munro, M.H.G.; Prinsep, M.R. Marine natural products. Nat. Prod. Rep. 2015, 32, 116-211, and earlier reports in the series.

2. Newman, D.J.; Cragg, G.M. Marine natural products and related compounds in clinical and advanced preclinical trials. J. Nat. Prod. 2004, 67, 1216-1238.

3. Simmons, T.L.; Andrianasolo, E.; McPhail, K.; Flatt, P.; Gerwick, W.H. Marine natural products as anticancer drugs. Mol. Cancer Ther. 2005, 4, 333-342.

4. Molinski, T.F.; Dalisay, D.S.; Lievens, S.L.; Saludes, J.P. Drug development from marine natural products. Nat. Rev. Drug Discov. 2009, 8, 69-85.

5. Liu, Y. Renaissance of marine natural product drug discovery and development. J. Mar. Sci. Res. Dev. 2012, 2, e106.

6. Ali, H.A.J.; Tamilselvi, M.; Marine ascidians: A promising resource for bioactive compounds. In Marine Pharmacognosy: Trends and Applications; Kim, S.-K., Ed.; CRC Press: Boca Raton, FL, USA, 2013; pp. 173-189.

7. Menna, M. Important classes of bioactive alkaloids from marine ascidians: Structures, isolation and bioactivity. Curr. Top. Med. Chem. 2014, 14, 207-223.

8. Wright, A.E.; Forleo, D.A.; Gunawardana, G.P.; Gunasekera, S.P.; Koehn, F.E.; McConnell, O.J. Antitumor tetrahydroisoquinoline alkaloids from the colonial ascidian Ecteinascidia turbinata. J. Org. Chem. 1990, 55, 4508-4512.

9. Rinehart, K.L.; Holt, T.G.; Fregeau, N.L.; Stroh, J.G.; Keifer, P.A.; Sun, F.; Li, L.H.; Martin, D.G. Ecteinascidins 729, 743, 745, 759A, 759B, and 770: Potent antitumor agents from the Caribbean tunicate Ecteinascidia turbinata. J. Org. Chem. 1990, 55, 4512-4515.

10. Rinehart, K.L., Jr.; Lithgow-Bertelloni, A.M. Dehydrodidemnin B. WO9104985 A1, 19 April 1991.

11. Rinehart, K.L., Jr.; Gloer, J.B.; Cook, J.C., Jr.; Mizsak, S.A.; Scahill, T.A. Structures of the didemnins, antiviral and cytotoxic depsipeptides from a Caribbean tunicate. J. Am. Chem. Soc. 1981, 103, 1857-1859. 
12. Lindquist, N.; Fenical, W.; van Duyne, G.D.; Clardy, J. Isolation and structure determination of diazonamide A and B, unusual cytotoxic metabolites from the marine ascidian Diazona chinensis. J. Am. Chem. Soc. 1991, 113, 2303-2304.

13. Murphy, C.D. New frontiers in biological halogenation. J. Appl. Microbiol. 2003, 94, 539-548.

14. Sesin, D.F.; Ireland, C.M. Iodinated phenethylamine products from a didemnid tunicate. Tetrahedron Lett. 1984, 25, 403-404.

15. Carroll, A.R.; Bowden, B.F.; Coll, J.C. Studies of Australian ascidians. II. Novel cytotoxic iodotyrosine-based alkaloids from colonial ascidians, Aplidium sp. Aust. J. Chem. 1993, 46, $825-832$.

16. Smith, C.J.; Venables, D.A.; Hopmann, C.; Salomon, C.E.; Jompa, J.; Tahir, A. Faulkner, D.J.; Ireland, C.M. Plakinidine D, a new pyrroloacridine alkaloid from two ascidians of the genus Didemnum. J. Nat. Prod. 1997, 60, 1048-1050.

17. Ford, P.W.; Davidson, B.S. Plakinidine D, a new pyrroloacridine alkaloid from the ascidian Didemnum rubeum. J. Nat. Prod. 1997, 60, 1051-1053.

18. Solano, G.; Motti, C.; Jaspars, M. New iodotyramine derivatives from Didemnum rubeum. Tetrahedron 2009, 65, 7482-7486.

19. Won, T.H.; Jeon, J.-E.; Lee, S.-H.; Rho, B.J.; Oh, K.-B.; Shin, J. Beta-carboline alkaloids derived from the ascidian Synoicum sp. Bioorg. Med. Chem. 2012, 20, 4082-4087.

20. Won, T.H.; Jeon, J.-E.; Kim, S.-H.; Lee, S.-H.; Rho, B.J.; Oh, D.-C.; Oh, K.-B.; Shin, J. Brominated aromatic furanones and related esters from the ascidian Synoicum sp. J. Nat. Prod. 2012, 75, 2055-2061.

21. Ahn, C.-H.; Won, T.H.; Kim, H.; Shin, J.; Oh, K.-B. Inhibition of Candida albicans isocitrate lyase activity by cadiolides and synoilides from the ascidian Synoicum sp. Bioorg. Med. Chem. Lett. 2013, 23, 4099-4101.

22. Won, T.H.; You, M.; Lee, S.-H.; Rho, B.J.; Oh, D.-C.; Oh, K.-B.; Shin, J. Amino alcohols from the ascidian Pseudodistoma sp. Mar. Drugs 2014, 12, 3754-3769.

23. Fujii, K.; Ikai, Y.; Mayumi, T.; Oka, H.; Suzuki, M.; Harada, K.-I. A nonempirical method using LC/MS for determination of the absolute configuration of constituent amino acids in a peptide: Elucidation of limitations of Marfey's method and of its separation mechanism. Anal. Chem. 1997, 69, 3346-3352.

24. Fujii, K.; Ikai, Y.; Oka, H.; Suzuki, M.; Harada, K.-I. A nonempirical method using LC/MS for determination of the absolute configuration of constituent amino acids in a peptide: Combination of Marfey's method with mass spectrometry and its practical application. Anal. Chem. 1997, 69, 5146-5151.

25. Gao, H.; Kelly, M.; Hamann, M.T. Bromotyrosine-derived Metabolites from the Sponge Aiolochroia crassa. Tetrahedron 1999, 55, 9717-9726.

26. Rasmussen, T.; Jensen, J.; Anthoni, U.; Christophersen, C.; Nielsen, P.H. Structure and synthesis of bromoindoles from the marine sponge Pseudosuberites hyalinus. J. Nat. Prod. 1993, $56,1553-1558$.

27. Morel, A.F.; Flach, A.; Zanatta, N.; Ethur, E.M.; Mostardeiro, M.A.; Gehrke, I.T.S. A new cyclopeptide alkaloid from the bark of Waltheria douradinha. Tetrahedron Lett. 1999, 40, 9205-9209. 
28. Segraves, N.L.; Crews, P. Investigation of brominated tryptophan alkaloids from two Thorectidae sponges: Thorectandra and Smenospongia. J. Nat. Prod. 2005, 68, 1484-1488.

29. Van, L.T.K.; Hung, T.M.; Thuong, P.T.; Ngoc, T.M.; Kim, J.C.; Jang, H.-S.; Cai, X.F.; Oh, S.R.; Min, B.-S.; Woo, M.H.; et al. Oleanane-type triterpenoids from Aceriphyllum rossii and their cytotoxic activity. J. Nat. Prod. 2009, 72, 1419-1423.

30. Johansson, M.; Karlsson, L.; Wennergren, M.; Jansson, T.; Powell, T.L. Activity and protein expression of $\mathrm{Na}^{+} / \mathrm{K}^{+}$ATPase are reduced in microvillous syncytiotrophoblast plasma membranes isolated from pregnancies complicated by intrauterine growth restriction. J. Clin. Endocrinol. Metable 2003, 88, 2831-2837.

31. Oh, K.-B.; Kim, S.-H.; Lee, J.; Cho, W.-J.; Lee, T.; Kim, S. Discovery of diarylacrylonitriles as a novel series of small molecule sortase A inhibitors. J. Med. Chem. 2004, 47, 2418-2421.

32. Chung, S.C.; Jang, K.H.; Park, J.; Ahn, C.-H.; Shin, J.; Oh, K.-B. Actin depolymerizing effect of trisoxazole-containing macrolides. Bioorg. Med. Chem. Lett. 2011, 21, 1958-1961.

33. Oh, K.-B.; Lee, J.H.; Chung, S.-C.; Shin, J.; Shin, H.J.; Kim, H.-K.; Lee. H.-S. Antimicrobial activities of the bromophenols from the red alga Odonthalia corymbifera and some synthetic derivatives. Bioorg. Med. Chem. Lett. 2008, 18, 104-108.

(C) 2015 by the authors; licensee MDPI, Basel, Switzerland. This article is an open access article distributed under the terms and conditions of the Creative Commons Attribution license (http://creativecommons.org/licenses/by/4.0/). 